\title{
THE CONSTRUCTION OF CHILDREN MORAL REASONING IN STRENGTHENING SELF-CONTROL
}

\author{
U'um Qomariyah, Qurrota Ayu Neina \\ Faculty of Language and Arts, Universitas Negeri Semarang, Indonesia \\ Jalan Sekaran Gunungpati Semarang, Indonesia \\ Corresponding Author: uum@mail.unnes.ac.id
}

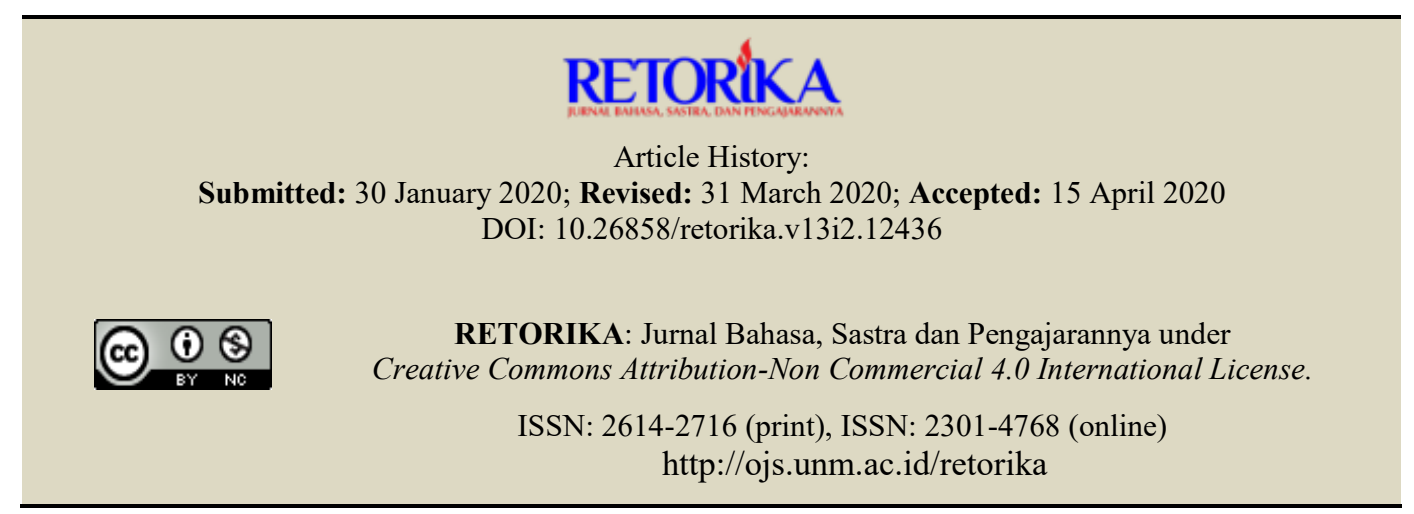

\begin{abstract}
Self-control is achieved by popular children stories, by which they are able to help children see themselves and change their way of life to ensure a sustainable future. Besides, the stories also function to identify, investigate, evaluate, and take appropriate actions in order to maintain, protect, and develop one's mentality and characters, environment, and society. The purpose of this study was to reveal the construction of children moral reasoning in children stories contained in a national daily newspaper of Suara Merdeka in 2018. As based on the research substance, this present study relied on the qualitative and critical analysis methods. The results suggests that children, as the main characters in every story, have morals and do reasoning in dealing with problems. The construction of moral reasoning is classified into three, i.e., construction of moral reasoning in children's relationship with family, with friends, and with society. Such constructions will give relevance to children's self-control in solving various problems and coping with pressures.
\end{abstract}

Keywords: children stories, moral reasoning, self-control

An analysis of developmental psychology indicates that childhood is a critical period for children's mental development, meaning that the formation of mentality and intelligence at this period will define their characters. In this case, literature serves as the right option, as in line with Shuterland (1985: 143), pointing out that children stories serve as a medium to give meaning to life in different cultures and civilizations. Similarly, Medress (2008: 2) opines that the benefits of lit- erature (children stories) for education are experienced through their roles in carrying values and containing lessons explicitly or implicitly, including in achieving children's self-control until their adulthood. For this reason, children stories are essential to shaping children's mentality, characters, and self-development.

Technological development influences children's mindset in almost every aspect of life, as well as taking them to the dynamics of social 
and cultural changes in society. Changes with distance lead to the process of bringing children, teenagers, and even the elderly to cosmopolitanism, so that it raises cultural shifting and science imparity.

Cultural shifting, science imparity, along with the changing era, cause "frictions" that can rapidly or slowly bring up hegemony and dominance. Thus, many crimes, low self-control, and suicides occurring to children are not very surprising.

On the other hand, honesty and kindness sometimes should compromise with arrogance and dominance of a particular community that will later raise unbalanced patterns in children's conscience. Unbalanced patterns will heavily affect the way they overcome problems once they are grown-ups. This also depicts that the goals and roles of scientists and experts in creating science as the light of civilization and discovery tool of life values towards a better way have been increasingly invisible and irrelevant to the current age.

On that ground, it is essential to get a reposition of science roles as the light of the world to always strengthen morals and science idealism as the embodiment of meaningful characters by bringing back the actualization of children stories in voicing moral values and self-control achievement. Some previous studies conducted by Erle (2017), Heath (2017), and Alkestrand (2018) find out the linkage between children's morals and self-control, including character strengthening.

Children stories serve as education facilities that introduce the concepts of moral and surrounding environment to children. In this context, children stories are not merely artifacts that reflect today's ideology with values and morals, yet they are also the representations of values that are considered crucial in society (Boudreaux, 2006; Adugna, 2015). Children's literature is considered to offer something that can drive one's soul, feeling, and even body towards gentleness, sensitivity, and humanity.

Nevertheless, the significance of children stories as part of self-control achievement is not complemented with the existence of popular children stories spread over, recorded, and read by children. The function of stories is mostly about entertainment and seem to be free from the concept of value strengthening. Lukens (2003: 4) argues that entertainment is one of the important aspects to children, yet understanding and reasoning also play a vital role to them. This notion implies that understanding and entertainment have become significant unity, which is expected to be integrated into children stories. In principle, arts are called duice et utile (beautiful and useful). Nurgiyantoro (2010: 31) terms arts with sweet and useful. These beauty and usefulness become a basis that children stories should be entertaining and giving an understanding for value (self-control) strengthening. In the same tune, Hunt (as cited in Neina, 2015) claims that in the context of value strengthening, ideology in a story is delivered to children as a means to shape characters explicitly.

However, a story that explicitly relies on morals and neglects entertainment will also be ignored. This kind of story views children as a figure that should be fully dictated and overseen, without providing them the freedom to give opinions. Unsurprisingly, children stories from other countries, particularly Europe, draw more interest from Indonesian children than the original stories from Indonesia. In the perspective of vocalization (Qomariyah, 2005), children are regarded as an object.

Simply put, there is a solid match that synergizes in constructing unique children stories for them to be attractive, as well as delivering moral values as in accordance with children's moral development. Therefore, self-control strengthening can be reached. Similarly, Kohlberg (1995:23) notes that moral values always have reasoning because in essence, morals do not only understand what is good or bad, but also understand the principle of constructing good and bad values (moral reasoning). The construction of moral values then generates reasoning, i.e., regarding the way of thinking and rationalization of the inception of moral values, specifically those in children stories.

Kohlberg (1981:15), through moral reasoning theory, explains the definition of moral using several terms, such as moral reasoning, moral thinking, and moral judgment; moral reasoning is the most popular term among others. Moral reasoning emphasizes on reasons for an action an individual performs, meaning that it is more than just giving meaning to the action. Nonetheless, Kohlberg (1981:24) does not focus on one's statement about whether or not an action is wrong, instead, focusing on the reasoning towards the action.

Various studies conducted by Kohlberg in 
the development of human moral reasoning reveal that people give reasoning based on certain moral considerations, e.g., one shows that cheating is wrong as $\mathrm{s} /$ he can get caught; another one points out that cheating is wrong as it undermines the trust that is necessary for societal life.

This indicates meaningful differences in a person's moral views (Duska \& Whelan, 1982: 57). Nonetheless, different reasons people express in rationalizing their actions have structures (Magnis-Suseno, 2000: 156). Such structures are then developed by Kohlberg, becoming a theory of human moral reasoning development. Konhberg (1980: 29-37) claims that pre-conventional, conventional, and post-conventional moral reasoning are identified by children moral development.

The Pre-Conventional Reasoning is the lowest level of human reasoning, in which good and bad judgment are interpreted through external reward and punishment (Santrock, 2012: 119). This type of reasoning consists of two stages, including stage (1): orientation of punishment and obedience; stage (2): orientation of instrument relativist as the stage when children only mind their own interest about the right things that will also be applied to other people.

The Conventional Reasoning serves as the second or intermediate reasoning where one starts to apply particular standards, yet the standards are set by other people (Santrock, 2007: 119). This level of reasoning encompasses two stages, including stage (3): orientation of becoming part of "good children" and "sweet children" groups, or usually called as mutual interpersonal expec-tation stage since appreciation, trust, and loyalty have emerged; stage (4): orientation of law and order as the stage is based on the system of order in society, law, justice, and obligation.

Post-conventional, Autonomous, or Principled Reasoning, in this level, there is an obvious effort to give meaning to moral values and truth principles that are separable from group or individual authorities. There are two stages, na-mely stage (5): orientation of sociolegality con-tract where individuals act right with a tenden-cy to be comprehended in terms of general indivi-dual rights and measures that have been examined and approved by community members; stage (6): orientation of universal ethics principle when individuals develop standards and can overcome the conflict between law and conscience. In this stage, they reason that every decision follows conscience, although it may be risky.

\section{METHOD}

This study relied on the critical analysis method, i.e., a method used to reveal the construction of pre-conventional, conventional, and post-conventional reasoning. A critical analysis, or usually called a critical study, was utilized by considering the uniqueness of children stories that comprised integrative elements and structures as the reflection of life. The uniqueness focuses on a study of reasoning that was implemented in the characters and morals of the story characters.

The data source was 21 children short stories in a national daily newspaper of Suara Merdeka in 2018. All the stories were selected based on the following reasons, including (1) children short stories in this newspaper were frequently used as the reading source of children; (2) the stories considerably tell about children's reality of life; (3) the stories had positive moral values that can be used as a source of value reasoning in children.

In addition, the data were collected from library research, observation, and interview. The data were excerpts containing the construction of children pre-conventional moral reasoning, conventional moral reasoning, and post conventional moral reasoning as an effort to achieve self-control.

After finding, formulating, and analyzing popular children stories, the next stage was collecting research data, i.e., words, phrases, or sentences, in the form of a data card that was in accordance with the research target. Further, the data were classified by sorting and selecting data as in line with the problem discussed in this presented study. After classifying the data, the analysis and critical study of children moral reasoning in popular children stories were carried out.

Data analysis and interpretation were based on the stages proposed by Miles and Huberman (2009), as follows: (1) data collection; (2) data reduction, reducing (eliminating) data irrelevant to the study; (3) data display in the form of classifying, displaying, elaborating, describing, and the like; (4) conclusion drawing or data and results verification.

Following the data of children stories in 2018 , there are 21 children stories with various 
conflicts. However, not all of those stories have children as the main characters, although the stories are categorized as children stories. Some of them have adult characters, and even four stories get animals as the characters; such stories with animal characters are regarded as fables, so that they are not examined and analyzed.

By basing on the disclosure of the result of the construction of children moral reasoning, the data used in the analysis are stories with children as the main characters. Besides the complexity of the children stories themselves, taking the construction of children moral reasoning must be seen from children's viewpoint. Hence, only 15 out of 21 stories serve as the data source.

Table 1. List of Children Stories in the Aforementioned Daily Newspaper

\begin{tabular}{ll}
\hline \multicolumn{1}{c}{ Title } & \multicolumn{1}{c}{$\begin{array}{c}\text { Date of } \\
\text { Publishment }\end{array}$} \\
\hline $\begin{array}{l}\text { Kupu-kupu Bersayap Merah } \\
\text { Jambu }\end{array}$ & 23 January 2018 \\
Ada Apa dengan Mimo? & 15 January 2018 \\
Semut Rangrang dan Ayam & 8 January 2018 \\
Abil dan Kakek Penyelamat & 1 January 2018 \\
Penjaga Sawah & 30 January 2018 \\
Rossea dan Impiannya & 12 February 2018 \\
Mangrove di Pantai Panjiwa & 04 March 2018 \\
Bebek-Bebek yang Berbaris & 11 March 2018 \\
Nyanyian Penyemangat & 25 March 2018 \\
Hidup & \\
Pelangi Putih & 08 April 2018 \\
Tersesat di Kebun Binatang & 15 April 2018 \\
Permintaan Zallumy & 22 April 2018 \\
Menunggu Angsa Bertelur & 16 July 2018 \\
Toko Roti Nyonya Rumika & 23 July 2018 \\
Riyu Pasti Bisa & 30 July 2018 \\
Pena Cantik Ibel & 6 August 2018 \\
Lomba Membaca Puisi & 13 August 2018 \\
Pak Seger dan Pak Waras & 20 August 2018 \\
Kokok si Kiko & 27 August 2018 \\
Mauri yang Baik Hati & 4 September 2018 \\
Sostel dan Sayur & 9 October 2018 \\
\hline &
\end{tabular}

The data source is then reclassified following the pattern of children's relationship with others. Below are the results of children stories in Suara Merdeka national daily newspaper in 2018. It is shown that two stories that use adult characters entitle Toko Roti Nyonya Rumika and Pak Seger dan Pak Waras. In contrast, stories with animal characters and characterizations are Semut Rangrang dan Ayam, Penjaga Sawah, Riyu Pasti Bisa, and Kokok si Kiko. Here is the complete list of children stories in the aforementioned daily newspaper in table 1 .

The above data in the table will be classified into three parts, i.e., construction of moral reasoning in children's relationship with family, with friends, and with society. The results of the presentation and classification are elaborated below. Given the limitation of total pages, not all elaborated data are displayed; only representatives of each classification.

\section{FINDINGS AND DISCUSSION}

\section{Findings}

\section{The Construction of Moral Reasoning in Child- ren's Relationship with Family}

As part of the interpersonal relationship, like a binary opposition, children will indeed be children when they are contrasted to parents, if it is viewed from a visible principle, e.g., age. In this case, children are widely associated with the existence of parents as part of a family. Alongside parents, siblings also play an important part in children's life. In this principle, a child surely desires an ideal thing from the family's perspective, such as becoming a decent child as what the parents wish for.

Moral reasoning in children's relationship with family is seen in a short story entitled $A d a$ Ada Apa dengan Mimo (translation: What's Wrong with Mimo). The story tells about a boy named Mimo who is ill as he often buys unhealthy foods in school. He ignores his mother's advice beforehand and keeps feeling safe to consume such foods. As a result, he suffers from unbearable stomach pain that leads to more frequent bowel movements.

From this pain, moral reasoning in the form of realizing one's own mistakes turns up. This kind of moral includes in the first stage of reasoning, i.e., pre-conventional, that is oriented to reward and punishment. The complete excerpt is provided as follows.

What did you eat? You did not even finish your home-packed meal."

"I drank syrup, ate steamed fish dumplings and fritters, mom," said Mimo with tears.

"I am sorry, mom. I promise that I will not eat unhealthy foods anymore." 
Mom smiles. While hugging Mimo, she said, "It is okay, Mimo. You can do it once in a while. But, is not it better to eat homepacked meal? It is both healthy and economical, and you can even save your pocket money to buy other stuff."

"Yes, mom. From today, I promise you to eat foods you cook frequently and not to buy unhealthy ones," said Mimo with tears and regret (Ada Apa dengan Mimo, 15 January 2018).

The moral value of admitting his mistakes is oriented to the construction of pre-conventional reasoning. Pre-conventional reasoning is the lowest level of human reasoning, in which good and bad judgment are interpreted through external reward and punishment.

It is said the lowest level due to the fact that a person will do good deeds or have morals if $\mathrm{s} / \mathrm{he}$ gets something in return (reward). Moreover, one commits good deeds by the reason that if $s / h e$ does otherwise, s/he will get punishment. The realization is then strengthened by Tito's statement that justifies and clarifies his mom's advice, as provided below.

Tito's mother is right. During this time, he is often impatient. "You need to learn how to be patient for the result of what you work on will be more satisfying. Trust me." His mother then hugs him. "Thank you, mom." Tito hugs his mother tightly. He is grateful for having an indulgent mom (Bebek-Bebek yang Berbaris, 11 March 2018)

The moral value of admitting one's own mistakes in Tito's character in the Bebek-Bebek yang Berbaris (translation: Lined up Ducks) short story is oriented to the construction of preconventional reasoning. Such reasoning is the lowest level of human reasoning, in which good and bad judgment are interpreted through external reward and punishment.

The same moral construction is preconventional since reward or punishment is clearly seen in the following excerpt. In a short story entitled Mauri yang Baik Hati (translation: The Kind-Hearted Mauri), Mauri gets a jacket and necklace for her good deeds. She likes them so much. However, her mom realizes that the jacket and necklace given to her, in fact, belong to the King. Mauri's mom asks her to give them back. At first, Mauri refuses to do so until her mom says
"God will replace them with better things". Mauri changes her mind and is willing to return the jacket and necklace to the King. It is shown that Mauri changes her mind and does what her mom asks her to do because she hopes that she gets something in return from God, meaning that she wants a reward "something in return from God". Below is the complete excerpt.

\section{“But, mom...," Mauri feels disappointed. "I like this jacket and necklace that much.” \\ "You better give them back. God will
replace them with better things."}

Mauri obeys her mother. In that afternoon, she hurries towards the King's palace and tells everything once she arrives. Fortunately, the King trusts her. The princess looks excited seeing her favorite stuff is back (Mauri yang Baik Hati, 4 September 2018)

The construction of moral reasoning Mauri has shown refers to the pre-conventional stage as a reward has an interesting side. The level of reward, however, is an abstraction. A reward from God as one's belief to his/her God is an abstract thing since $\mathrm{s} / \mathrm{he}$ has no idea how the reward will be like. In other words, a reward from God in the pre-conventional reasoning is a dogmatic case, which I think, quite higher than a reward given by humans that is usually concrete. Nonetheless, as part of a reason for performing something, a reward has become Mauri's reason to do the right thing.

Furthermore, the construction of conventional reasoning is seen in the second conventional moral reasoning with bravery as the moral. Conventional reasoning serves as the second or intermediate reasoning where one starts to apply particular standards, yet the standards are set by other people. In this reasoning, the moral is included in the category of "good children" and "sweet children", or usually refers to the stage of mutual interpersonal expectation, relationship with others, and interpersonal conformity, i.e., a person has appreciated trust, concern, and loyalty towards other people as the basis of his/her moral reasoning. This stage reveals a transition from childhood to adolescence, which frequently adopts parent's moral standards for they be considered a good child. 


\begin{abstract}
"Do not separate," said mother. However, while Nina is busy looking at elephants, it turns out that her sibling, father, and mother are unseen. Nina is confused and almost crying. She is running around looking for her family, yet
\end{abstract}

she cannot find them. She suddenly remembers her mother's words. When Nina gets lost, she must be brave to ask someone. "Ma'am, can you please help me?" said Nina while approaching a woman who passes her. "Yes, what is wrong, kid?" Asked the woman. "Did you see my mom?" Nina looks frightened (Tersesat di Kebun Binatang, 15 April 2018)

The above excerpt in Tersesat di Kebun Binatang (translation: Getting Lost at the Zoo) depicts that Nina is getting lost at the zoo. She is then reminded by her mother's words to ask for help if she loses her way in a crowded place. The behavior of remembering and getting to do the message describes a conventional moral reasoning construction in the form of "good children" or "sweet children".

The construction of the relationship between children and their families is also shown by Mauri's character. Mauri is a poor girl who lives with her mother because his father died long ago. Mauri's mother is sick and only lays in bed. Mauri is very sad. Some valuables in her house have been sold for daily needs.

Truthfully, Mauri is good at cooking. She learns how to cook from her mother, who used to have a food stall. Nevertheless, the food stall is now closed because Mrs. Melisa is sick and lacks funds.

"I have to work," said Mauri to herself. However, she gets confused. In order to work, she will leave her mother in quite a long time (Mauri yang Baik Hati, 4 September 2018).

Mauri's strong determination to work and help her mother fulfilling daily needs is the moral of being a hard-working person. Before her mother gets sick, she opened a food stall where Mauri helped her along; yet, the food stall is now closed because her mother is sick. Mauri does not want to burden her mother by only relaxing and not helping anything at home. Therefore, she decides to go to work. As a child, working is considered unreachable, so that it is normal for Mauri to get confused about the work she will carry out.
The moral of being a hard-working person Mauri has is post-conventional moral reasoning construction. Such a construction is autonomous and stands alone. As a child, Mauri can think and make her own decisions to interpret moral values and truth principles, and implement them. She desires to work and helps her mother, not because she is asked to do so. Instead, the situation encourages her to do something with principles that she understands the truth. The principles of truth she has done are genuinely from herself, without any encouragement from her parents or specific communities.

\section{The Construction of Moral Reasoning in Children's Relationship with Friends}

In addition to being part of a family, children also have their social side with friends at home or in school. Children's world is the world of play. Friends have become one of the purposes of existence recognition and self-actualization. They are the second family to children.

An example of moral reasoning construction in children's relationship with friends is done by the main characters of Arif and Andi in a short story entitled Menunggu Angsa Bertelur (translation: Waiting for a Goose to Lay Eggs). This story tells about two boys who scramble to find goose eggs owned by Mr. Rokan. They have known the exact time the goose will lay eggs, so that they will hide and wait for it every day. They agree that the fastest one who gets the eggs will get them. However, when waiting for the eggs, Arif's mother suddenly asks him to buy sugar. After coming back, he sees that Andi already has the eggs. Again, he is very disappointed. His heart and face are gloomy at once. Little does he regret the situation when he has to buy sugar. Nevertheless, he then realizes that what he does is wrong. Arif realizes that his lies to Mr. Rokan are improper conducts, including the regrets he once feels and blames Andi.

The moral value of Arif who is brave to admit his mistakes is in the construction of preconventional reasoning, and in the stage of instrument relativist orientation. Initially, Arif regretted the situation. He blamed his mother for asking him to buy sugar at important moments of waiting. However, Mr. Rokan is aware of Arif's behavior, by which he advises Arif. Arif now regrets his actions. Mr. Rokan who is lied to, 
whose goose eggs taken by Arif and Andi, apparently still gives them advice well.

\section{Arif realizes that he has made mistakes again. Besides lying, he is also intolerant. Arif finally return the eggs to Andi (Menunggu Angsa Bertelur, 1 July 2019) \\ "You are the one who gets these eggs, so that you deserve them more," said Arif. \\ Arif also apologizes to Mr. Rokan, and feels so sorry for lying to him.}

Another moral value is being helpful, as indicated by Ibel, in the following excerpt.

"Calm down, Ratna. You do not need to be worried. I will repair the pen, and you can use it tomorrow," said Ibel to Ratna, and witnessed by other friends. Ratna begins to calm down and looks happy. She now can smile, and thank Ibel (Pena Cantik Ibel, 16 August 2018)

The moral value of being helpful as shown by Ibel in the story Pena Cantik Ibel (translation: Ibel's Beautiful Pen) refers to post-conventional, autonomous, or principled reasoning construction. This is based on Ibel's behavior that clearly interprets moral values and truth principles that can be applied, regardless of the authority of groups or people who hold these principles, and whether or not the individual is included in those groups. Ibel is being helpful as the moral value without any coercion from others. She has been good from the beginning by lending her pen, and even still being good when her friends get the pen broken. She also tries to repair the pen. She does this without being told to and complimented by other people.

\section{The Construction of Moral Reasoning in Children's Relationship with Society}

The third reasoning construction is in children's relationship with society. Although children have not been given full responsibility as a whole human being, yet they have moral responsibility as a member of the community. In this section, the construction of moral reasoning in children's relationship with society will be elaborated.

The character in this short story is Abil. Since childhood, Abil is different from Puri, his older sister. He is a quite lazy person, especially when it comes to studying. Being confused and sleepy is the reason if his mother or sister brings him a book. Abil prefers spending time watching television or playing games. In fact, he is now in the first grade of elementary school, yet he still gets confused to distinguish the letter "b" and "d".

On that day, Abil bravely goes out of the house on a bicycle through the village. However, he forgets the way back to his grandmother's house. He gets lost. Abil passed some alleys, but unfortunately, the alleys do not go to his grandmother's house. He is confused. He cannot read the directional signage provided, so that it is useless. He has contacted his mother, but she suggests him to read the directional signage. Since he cannot read, he asks an elderly. Since then, Abil is aware of the importance of learning about letters, so that he can read.

The above excerpt reveals Abil's moral of being brave which is oriented to the pre-conventional reasoning construction. The pre-conventional level is the reasoning that is based on good and bad judgments, which are interpreted through external reward and punishment. Getting lost serves as the punishment for Abil in the story. This leads him to bravery to ask someone to show the direction towards his grandmother's house.

The construction of the relationship between children and society is also seen in a short story entitled Nyanyian Penyemangat Hidup (translation: A Singing of Life Encouragement). The story tells about a girl named Lala who loves singing and entertaining other people. Lala has the moral of being helpful, as shown in the following excerpt.

Thereafter, Mrs. Martha gets up from the bed and looks cheerful. "Thank you, Lala. Your singing has healed me," said Mrs. Martha. "I am happy that you get well, ma'am.

\begin{abstract}
You need to take a rest," said Lala. "I wish I could see you often, Lala. I want to hear you singing. Your singing can really make me encouraged and heal," said Mrs. Martha (Nyanyian Penyemangat Hidup, 25 March 2018).
\end{abstract}

The moral of being helpful to others is categorized in the construction of conventional reasoning as the second reasoning. Lala, as an individual, carries out the reasoning by starting to apply certain standards that are set by other people, i.e., the stage of orientation of being in 
"good children" and "sweet children" groups. This stage usually refers to the stage of mutual interpersonal expectation, relationship with other individuals, and interpersonal conformity, i.e., a person has appreciated trust, concern, and loyalty towards other people as the basis of his/her moral reasoning. This stage also shows a transition from childhood to adolescence, which frequently adopts parents' moral standards for they be considered good children.

Morals with the same construction of good children orientation are also seen in the expert in Mauri yang Baik Hati story, as provided as follows.

"Miss... May I ask for food? I have not eaten
today," asked an old man in shabby clothes.

Mauri comes near the old man. "Eat this, sir. Hopefully, you will be no longer starving."

"Thank you, Miss. Here is a thick floral jacket. Hope it suits you," the old man gives the jacket to Mauri (Mauri yang Baik Hati, 4 September 2018).

The above excerpt indicates that Mauri has the moral value of being helpful. It is regarded as the conventional reasoning construction. Such reasoning applies certain standards that are set by other people, i.e., the stage of orientation of being in "good children" and "sweet children" groups. The title of the story even depicts Mauri's behavior of being helpful for other people.

\section{Discussion}

As based on the results of this study, those children stories have three forms of moral reasoning constructions, which are shown through children's relationships with family, friends, and society. The stories comprise different levels of reasoning, i.e., pre-conventional, conventional, and post-conventional. Such differences influence children's reactions in dealing with a situation. The ability to manage behavior as in accordance with any situation is a life skill every child should have as a form of self-control.

Goldfried and Merbaum (in Ghufron, 2010) define self-control as an ability to arrange, guide, organize, and direct individuals to behave positively. The concept of self-control is very relevant to see the relationship between children and their surroundings (family, friends, and society), particularly in terms of attitude and standpoint. In the same tune, Mahoney and Thoresen (in Ghufron, 2010) claim that children with high self-control pay close attention to the appropriate ways to behave in various situations.

Self-control is required to help children resolve their limited ability and some detrimental things that may take place. This is strengthened by Colhoun and Acocella (in Ghufron, 2010) stating that there are two reasons for the importance of continuous self-control, including (1) children live with a group of people, and they need to control their behavior in satisfying desires, so that other people still feel convenient, and (2) society encourages children to constantly set better standards for them.

In relation to the levels of children's reasoning in the short stories, it is widely acknowledged that in the pre-conventional level, children can take several values of self-control, such as (1) do not take wrong actions which are not in compliance with moral values because they will get consequences as punishment; (2) thoughts about good deeds which are in accordance with moral values will keep children from punishment.

In the conventional level, children can take the value of self-control in the form of thoughts regarding a "good child" figure that will be loved by parents, friends, and society. Being aware of this kind of figure, children will always try to show the best version of them. Furthermore, this awareness will get them to understand that taking decent actions is necessary for facing problems. Such actions will make them be acknowledged and accepted by parents, friends, and society.

Meanwhile, in the post-conventional level, children can take the value of self-control in the form of realization to interpret and understand moral values and principles around their environment. By this, they will be able to sort out different actions and the consequences. This will help children be mature in thinking and taking actions, so that they will grow becoming a positive being.

There is a strong correlation between moral reasoning as done by children in children stories mentioned previously with their self-control. In the stories, they are the ones who act and determine their behavior following applicable norms and laws. Simply put, children who have moral reasoning, even with the lowest level, are able to control themselves. 
The ability of children who are individually able to guide, direct, and suppress their emotions and impulses towards a good direction indicates that they have self-control. If done continuously, the ability will shape a strong and integrative character of the children.

Self-control cannot be achieved instantly. It is a matter of maintaining the balance of children's reasoning and behavior through a continuous and sustainable process that is started from family, school, and society. In the same way, Calhoun and Acocella (1990) point out that self-control is one's effect on and regulation to-wards his/her physical and behavioral aspects, as well as a psychological process, or in other words, a set of process that binds him/her.

Self-control is functioned to limit people's attention to others, to limit their desire to control others in their surroundings, to limit them to behave negatively, and to help them fulfill their life necessities in a balanced manner. Those who have excellent self-control will attempt to meet their needs in a measure that suits the needs they want to meet. In this case, self-control is able to help individuals balance their life.

\section{CONCLUSION}

In order to see a comprehensive reasoning construction, the classification is based on the

\section{REFERENCES}

Adugna, A. B. (2015). How Green are Our Stories? Exploration of Ecological Subjectivities in Ethiopian Children's Literature. Journal of Language and Culture, 6 (5): 39-51.

Alkestrand, M. \& Owen, C. (2018). A Cognitive Analysis of Characters in Swedish and Anglophone Children's Fantasy Literature. International Research in Children's Literature 11 (1): 6579.

Boudreaux, B. (2006). The Representation of The Environment in Children's Literature. Thesis. University of New Orleans. http://scholarworks.uno.edu/cgi.viewcontent.cgi?article:13 $68 \&$ context $=\mathrm{td}$. Diakses Juni 2017.

Calhoun, J.F. \& Acocella, J.R. (1990). Psychology of adjustment and human relationship. Diterjemahkan oleh R.S. Satmoko, edisi ketiga. Semarang: IKIP Semarang Press.

Duska, R. \& Mariellen W. (1982). Moral Development: A Guide to Piaget and Kohlberg. New York: Paulist Press. construction of children's relationship with family, with friends, and with society.

First, the construction of children's relationship with family. There are some morals the children have, including (1) obeying parents' advice; (2) realizing mistakes; (3) being persis-tent; (4) being helpful; (5) being brave; (6) being polite; (7) being generous; and (8) being a hard working person.

Second, the construction of moral reasoning in children's relationship with friends is seen in the following data, (1) being humble, (2) being brave to admit mistakes; and (3) being helpful.

Third, the construction of moral reasoning in children's relationship with society includes (1) being brave; (2) being helpful; and (3) morals with the same construction, i.e., an orientation of good children is shown in Mauri yang Baik Hati excerpts.

Based on the result, there is a strong correlation between moral reasoning as done by children in children stories mentioned previously with their self-control. In the stories, they are the ones who act and determine their behavior following applicable norms and laws. Simply put, children who have moral reasoning, even with the lowest level, are able to control them selves.

EtxanizErle, X. \& López G. J. M. (2017). Children's Literature and Nation Building: The Basque Case. Children's Literature in Education Journal. 7 (1): 207-276.

Ghufron, M. N. \& Rini R. (2010). Teori-Teori Psikologi [Theories of Psychology]. Yogyakarta: Ar-Ruzz Media.

Heath, M. A., Kathryn S. \& Ellie Y. L. (2017). Using Children's Literature to Strengthen Social and Emotional Learning. School Psychology International, 38 (5): 541-56.

Kohlberg, L. (1980). "Stages of Moral Development as a Basis for Moral Education" dalam Brenda Munsey (Ed.). Moral Development, Moral Education, and Kohlberg: Basic Issues in Philosophy, Psychology, Religion, and Education. Birmingham Albama: Scott Religion Education Press.

Kohlberg, L. (1981). The Philosophy of Moral Development Stages and Idea. San Fransisco: Harper and Row. 
Kohlberg, L. (1995). Tahap-tahap Perkembangan Moral [Moral Development Stages]. Translation. John de Santo and Agus Cremers. Yogyakarta: Kanisius.

Lukens, R. J. (2003). A Critival handbooks of Children's Literature. New York: Longman.

Magnis-Suseno, F. (2000). 12 Tokoh Tokoh Etika Abad Ke-20. Yogyakarta: Kanisius.

Medress, A. (2008). Storybooks: A Teaching Tool for Sustainability.http://digitalcollections.sit.edu /cgi/viewcontent.cgi?article=1057\&context = isp_collection. Accessed on June 2017.

Miles, M. B. \&. Huberman, A.M. (2009). Analisis Data Kualitatif [Qualitative Data Analysis]. Translation Tjetep Rohendi Rohidi. Jakarta: UI Press.

Neina, Q. A., Mardikantoro H.B., \& Supriyanto T. (2015). Pengembangan Buku Pengayaan Menulis Cerita Anak Bermuatan Nilai Karakter Berdasarkan Content and Languange Integrated Learning (CLIL) untuk Siswa Sekolah Dasar Kelas Tinggi. Jurnal Seloka, 4(2):50-57.
Nurgiyantoro, B. (2010). Sastra Anak: Persoalan Genre. Jurnal Humaniora, 16 (2): 107-122.

Qomariyah, U. (2005). Citra dan Pencitraan Anak dalam Telaah Fokalisasi Mieke Bal: Kajian Novel Negeri Awan Merah Karya Fahri Asiza. Thesis. Yogyakarta: Universitas Gadjah Mada.

Santrock, J. W. (2011). Perkembangan Anak 1 [Child Development 1]. Translation Mila Rachmawati \& Anna Kuswanti. Jakarta: Erlangga.

Santrock, J. W. (2012). Perkembangan Anak 2 [Child Development 2]. Translation Mila Rachmawati \& Anna Kuswanti. Jakarta: Erlangga.

Suara Merdeka. (2018). Cerita Anak dalam Tabloid Yunior Suara Merdeka www. Suara merdeka. com.

Sutherland, R. (1985). Hidden Persuaders: Political Ideologies in Literature for Children. Children's Literature in Education, 16 (3): 143157. 